\title{
The Safety of Chelators for Iron Overload in Sickle Cell Disease: A Brief Systematic Review
}

\author{
Basseem Radwan \\ ORCID:0000-0002-8741-5801 \\ I. İpek Boşgelmez ${ }^{*}$, , $[\mathrm{PhD}]$ \\ ORCID:0000-0003-2528-1227
}

${ }^{1}$ Erciyes University, Faculty of Pharmacy, 38280, Kayseri, Turkey

${ }^{2}$ Erciyes University, Faculty of Pharmacy, Department

of Toxicology, 38280 Kayseri, Turkey

* Corresponding Author: I. I. jpek Bosgelmez,

Erciyes University, Faculty of Pharmacy, Department of Toxicology, 38280 Kayseri, Turkey

Ipek4477@gmail.com, ibosgelmez@erciyes.edu.tr

Tel:0 3522076666 (ext: 28326)

GSM: +90 5308355107

\section{ree) ABSTRACT Cem}

Sickle cell disease is a group of disorders that affects hemoglobin due to a mutation of the hemoglobin beta gene on chromosome 11. Patients have atypical hemoglobin molecules called hemoglobin S, which distort erythrocytes into a "sickle-shape". Typical symptoms of disease include periodic episodes of pain, repeated infections, and anemia. This disorder is abundant in sub-Saharan African countries, the Mediterranean region, and also appears in some southern provinces in Turkey. Because of the high concentration of hemoglobin $\mathrm{S}$ in patients, a high risk of chronic anemia and vaso-occlusive events, such as stroke may deteriorate suddenly. In these conditions, transfusion of blood, especially erythrocytes, can be life-saving. However, chronic blood transfusions may lead to iron overload in patients. Erythrocyte transfusion is associated with a higher risk in most patients with sickle cell disease than in the general population. Therefore, chelation therapy has become an important component of the transfusion program to prevent complications of iron accumulation in organs such as liver and heart. In this study, we sought to conduct a systematic review to assess the safety of iron chelating agents used by patients with iron overload mainly due to necessary blood transfusion regime. Our evaluation revealed that in general iron chelation therapy, either deferasirox, deferoxamine or deferiprone, remains the most effective and safest available method to treat iron overload in sickle cell disease. Furthermore, current reports do not reflect any significant safety concerns against the use of available chelators.

Key words: Sickle cell disease, transfusion-induced iron overload, iron chelation therapy, safety

Received: 13 June 2019, Accepted: 06 September 2019,

Published online: 30 September 2019

\section{INTRODUCTION}

Sickle cell disease (SCD) is one of the most common serious inherited hemoglobinopathies around the world [1]. Although the incidence of the disease is particularly high in the sub-Saharan region in Africa as well as in some Mediterranean countries including southern provinces of Turkey, it can be seen in many geographical regions around the world due to population movements $[2,3]$. SCD can be described as a group of disorders that affects hemoglobin $(\mathrm{Hb})$ because of a point mutation in hemoglobin beta gene (HBB) on chromosome 11 [4]. The disease occurs as a result of displacement of glutamic acid with valine in the sixth position of the beta globin chain of $\mathrm{Hb}$. This change induces the formation of hemoglobin $\mathrm{S}(\mathrm{HbS})$ instead of $\mathrm{HbA}$, which causes red blood cell (RBC) to become sickle-shaped paving the way to a group of acute and chronic complications such as vaso-occlusive crisis (VOC), acute chest syndrome, pain episodes, and recurrent infections [5]. Signs and symptoms of SCD usually begin in early childhood. In general, the term SCD is used to refer to several genotypes that lead to characteristic clinical syndrome, while the most common form is sickle cell anemia (SCA), particularly the homozygosity for the $\beta S$ allele [6].

The abnormal cation homeostasis in sickled RBCs causes cell dehydration, which leads to polymerization. As the polymer fibers extend, they deform the 
cells and hinder their elasticity along with rheological properties, resulting in RBC aggregation and vaso-occlusion [5]. Vaso-occlusion in SCD is a complex condition in which interactions between RBCs and endothelial cells, platelets, and leukocytes play a central role. Sickle RBCs are more adhesive to endothelial cells than normal erythrocytes. In addition, neutrophils adhere to the endothelium and the sickle RBCs can easily attach to these cells, thereby reduce blood flow and precipitate vaso-occlusion [5]. Hemolysis in SCD exists as both a cause and consequence of oxidative stress, and since sickle cells are rather unstable, they tend to have a shorter life span [7]. Oxidative stress related issues in SCD have been extensively evaluated and reviewed [8-10].

The diagnosis of SCD is based on $\mathrm{Hb}$ analysis to check for HbS. Since this assay is increasingly used in hemoglobin mass spectrometry and DNA analysis, these techniques involve protein electrophoresis or chromatography, which get increasingly affordable and common throughout the world, as this enables high-throughput testing. Diagnosis of SCD is usually performed in four different periods, namely preconception, prenatal, neonatal, and post-neonatal [5]. Screening during pregnancy, shortly after birth or in infancy, is carried out as a routine procedure in some countries [11].

\section{Treatment Options}

For SCD patients, choice of treatment had been a major problem for many years. However, today besides curative options such as hematopoietic stem cell transplantation and gene therapy, the efficient use of disease-modifying therapies acting as anti-sickling agents (e.g. hydroxycarbamide=hydroxyurea), blood/RBC transfusion routines, and novel FDA-approved medicines including L-glutamine, help to reduce the severity of the disease and possibly improve survival rates $[5,12]$. While the most effective option is hematopoietic stem cell, barriers to treatment include the limited suitability of healthy HLA-matched donors, possible transplant rejection, long-term adverse effects and problems related with affordability $[12,13]$. In the case of pharmacological treatment, there are two FDA-approved drugs, namely hydroxyurea and L-glutamine. Hydroxyurea is a ribonucleotide reductase inhibitor, and it has been suggested to confer multiple physiological effects, such as increasing $\mathrm{HbF}$ expression and decreasing the leukocyte count [5]. Although this drug may provide only limited response in some patients, it significantly reduces VOCs, hospitalization and mortality in some countries. In both low- and high-income countries, hydroxyurea may remain insufficient due to health infrastructure deficiencies, perceptions on carcinogenicity, teratogenicity and decreased fertility [14]. L-glutamine has been recently approved by the FDA due to its potential effect to reduce the rate of some complications including pain crises for the patients who may have a limited response to hydroxyurea or who may have unacceptable side effects [15]. This conditionally essential amino acid that is utilized for the synthesis of NAD, has been shown to be taken several times greater in sickle RBCs as compared to normal erythrocytes; moreover, clinical improvement in patients via increased NAD redox ratio by L-glutamine sickle cells has been documented [16].

\section{Blood Transfusion and Iron Overload in SCD}

Because of high $\mathrm{HbS}$ concentrations, SCD patients are at increased risk of exposure to vaso-occlusive events which may suddenly deteriorate. In these conditions, blood or especially RBC transfusion can be life-saving [17]. Transfusion not only reduces the concentration of $\mathrm{HbS}$ thus improving the microvascular flow, but also increases oxygen delivery to tissues. As a result, it can reduce the tendency for vaso-occlusion and reduce some of the most serious complications of SCD, including acute chest syndrome and stroke [18]. Regular (prophylactic) transfusions have been suggested to be effective in reducing the morbidity of most complications of SCD, and especially indicated in the prevention or treatment of stroke in pediatric population [19]. The decision to use chronic blood transfusion at the beginning of the treatment or after hydroxyurea depends on evolving evidence and specific patient conditions [17].

Despite aforementioned benefits, chronic transfusions may also lead to complications such as hemolytic transfusion reactions, alloimmunization (the immune response to donor's antigens), transfusion-transmitted infections in some circumstances, and last but not least "iron overload" [5].

As in the healthy population, iron is mostly stored in the macrophages of the liver, spleen and bone marrow and rarely exceed $2000 \mathrm{mg}$ in SCD patients without long-term blood transfusions [17]. However, when repeated blood transfusions are required, iron overload develops, and erythrocyte transfusion is associated with a higher risk in most patients with SCD than in the general population [17]. Wood et al. reported that all children in TWiTCH trial with 
an average age $<10$ years, and monthly transfusions over 4 years experienced iron accumulation in liver and spleen; while the iron deposition in kidney $(<80 \%$ of the patients) as well as in pancreas $(\sim 38 \%)$ were of also of note [20]. In the case of extrahepatic organs, a recent review [21] underlines the fact that although myocardial iron overload has been very rarely reported in $S C D$, transfusion therapy could also end up with a potentially fatal complication in some patients.

The available transfusion regimes are simple transfusion and exchange transfusion, and the former can be riskier regarding the possible increase in blood viscosity and in iron burden. The rationale behind exchange transfusion regime is removal of a part of the patient's blood and exchanging it with allogeneic blood, thus decreasing the concentration of HbS by dilution [22]. Phlebotomy cannot be used for transfusion-dependent patients with SCA, beta-thalassemia major, severe beta-thalassemia intermedia, myelodysplasia or aplastic anemia. Therefore, the only viable strategy is to control iron content of susceptible targets and to manage iron overload with relevant chelating agents in such cases when required [23].

\section{Iron Chelators of Choice in SCD}

Iron chelation therapy for patients receiving multiple transfusions has become an important component of the transfusion program to prevent complications of iron accumulation in organs [24]. Chelation treatment generally begins after two years of chronic transfusion or after transfusion of about $200 \mathrm{~mL}$ of erythrocytes per $\mathrm{kg}$ and when serum ferritin level exceeds $1000-1500 \mathrm{ng} / \mathrm{mL}$ or liver iron of more than $3 \mathrm{mg} / \mathrm{g}$ dry weight. The age of onset, type, and rate of blood transfusion affect the rate and degree of iron overload in the SCD patients [23, 25]. Similarly, the patient's age, presence of comorbidities, the side effects of agents, and patient preferences are among the factors to select the most appropriate chelating agent. There are three available iron chelators, namely deferoxamine (DFO), deferiprone (DFP), and deferasirox (DFX), along with some chelating agent combinations in the treatment of iron overload in SCD $[23,26]$.

Since DFO has to be administered via parenteral routes daily, the alternatives i.e. DFX and DFP available as oral pharmaceutical dosage forms have been preferred in view of better compliance; however, each has its own benefits and drawbacks [27]. Especially, DFX is the most preferred iron chelator for patients with SCD, because it is orally active and has a good benefit to toxicity rate. On the other hand, owing to its effects on cardiac iron overload, DFP has been suggested as the chelator of choice whenever there is evidence that iron deposition in heart is prominent [23]. Routinely, the serum ferritin level is monitored in each transfusion; liver iron is evaluated annually, and additional monitoring for drug toxicity for specific chelators is performed [26]. Therefore, our aim in the current systematic review was to evaluate the safety profiles of DFO, DFP, and DFX in the treatment of iron overload in SCD. To achieve this goal, we searched for relevant clinical studies in databases and reviewed the most appropriate reports in view of adverse reactions, other unwanted or unexpected consequences.

\section{Literature Search and Evaluation for Systematic Review}

We conducted this systematic review according to PRISMA-P protocols [28]. The electronic databases (PubMed, Scopus, Web of Science) and clinical trial registries (NIH Clinical Trials/EU Clinical Trials Register) were used to search for relevant articles in English. We used the search terms "sickle cell disease," "sickle cell anemia," "iron overload," "iron chelation", "safety," "adverse reactions," "deferoxamine," "deferiprone," "deferasirox", as well as the abbreviations "SCD," "SCA," "DFO,, "DFP" and "DFX." In PubMed search, the "clinical trials" filter was on. In all electronic databases, we searched for publications dating back to 10 years.

Both authors independently reviewed the abstracts that emerged from the described literature search as also summarized in Figure 1. After excluding duplicate publications, a total of 280 abstracts were reviewed. Full texts were assessed whenever abstracts were not sufficient to determine whether the references were to be included. Studies that passed the abstract review phase were excluded from this systematic review based on the following exclusion criteria: theoretical papers $(n=9)$, absence of safety data $(n=7)$ or lack of Iron Chelation therapy (ICT) data $(n=1)$, the number of patients with SCD less than $20(n=6)$ or if it focused on hematopoietic stem cell transplant (HSCT) $(n=1)$. The included studies $(n=11)$ were then assessed in detail by both authors. 


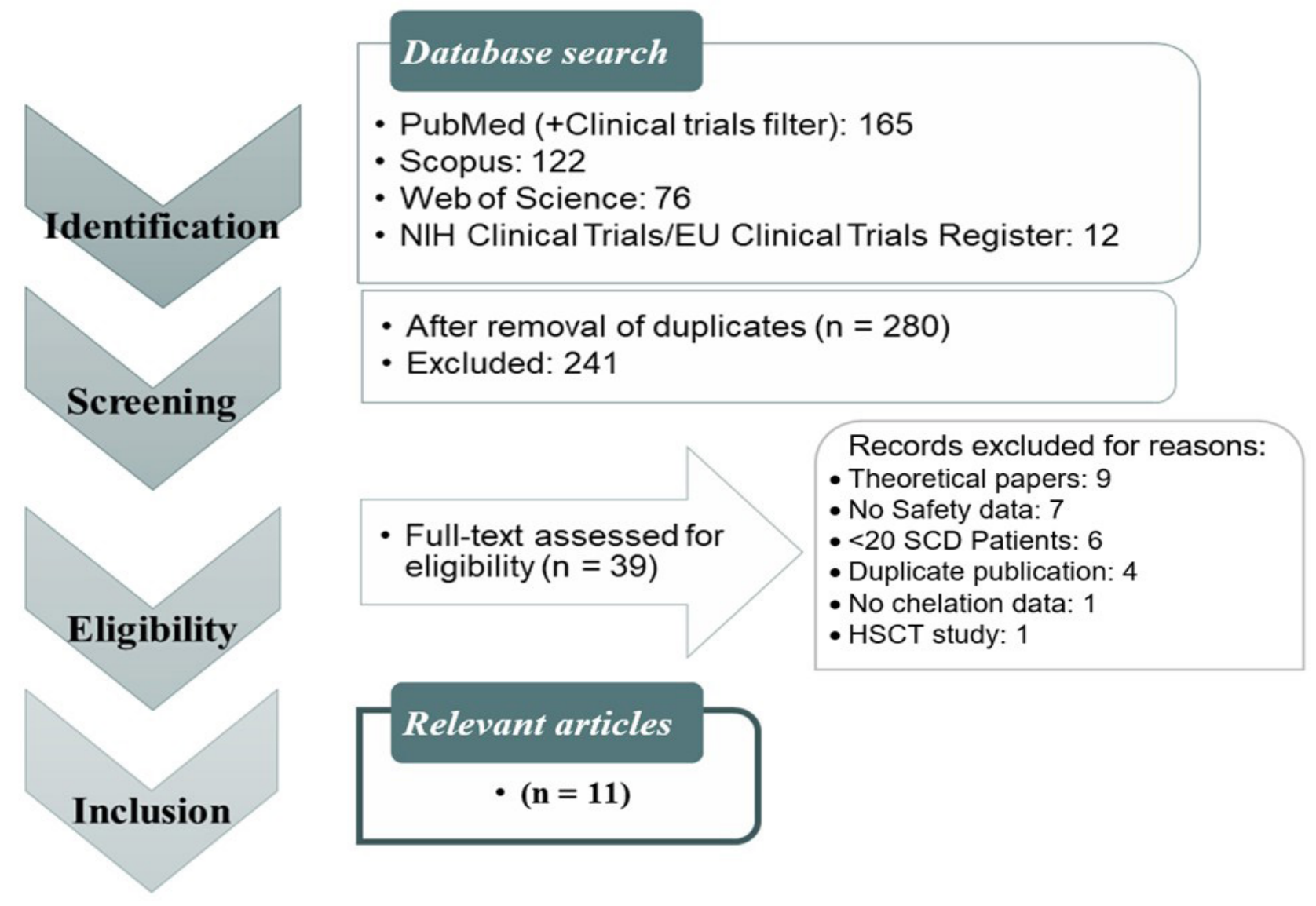

Figure 1: Flow diagram for the systematic review; HSCT, hematopoietic stem cell transplant.

After full-text examination of the 39 shortlisted studies, we concluded that 11 clinical trials including 1693 SCD patients met the pre-defined inclusion criteria (Antmen, 2019; Mohsin, 2018; Cancado, 2018; Calvaruso, 2014; Vichinsky, 2013; Goldberg, 2013; Alvarez, 2013; Jordan, 2012; Vichinsky, 2011; Kalpatthi, 2010; Cappelini, 2010). The iron chelating agent safety data extracted from these articles were summarized in Table 1.

Briefly, current evaluation highlights that iron chelation therapy presents a safe and effective method for treating transfusion-induced iron overload in SCD. Alvarez et al. [29] state that despite the possible adverse event (AE)s and rarely serious adverse event(SAE)s, iron chelation therapy appears to be more effective and safer than the hydroxyurea / phlebotomy proposed alternative treatment method.

The studies on chelators used for transfusion-induced iron overload in SCD during the last 10 years, have focused especially on DFX and DFO. In these studies, the frequency of iron chelator report was as follows: DFO $>$ DFX $>$ DFP. In line with this observation, the most frequent comparison between chelators was performed between DFO and DFX (five studies). Among the trials included in this review, only one of these was conducted using DFP [30]. 
Table 1: Studies evaluating iron chelation therapy (ICT) safety in the last 10 years.

\begin{tabular}{|c|c|c|c|c|c|}
\hline Study & Design & Locations & $\begin{array}{l}\text { Sample } \\
\text { Size }\end{array}$ & Population and Interventions & Outcome \\
\hline $\begin{array}{l}\text { Antmen } \\
2019 \\
{[32]}\end{array}$ & $\begin{array}{l}\text { Multicenter, } \\
\text { prospective } \\
\text { cohort study, } \\
3 \text { years }\end{array}$ & $\begin{array}{l}\text { Turkey } \\
\text { (30 centers) }\end{array}$ & $\begin{array}{l}\text { Total: } \\
n=439 \\
\text { SCA: } \\
n=24\end{array}$ & $\begin{array}{l}\cdot \text { TDT and SCA with iron overload } \\
\text { - Age: } 2-18\end{array}$ & $\begin{array}{l}\text {-AEs suspected to be related to DFX: } 9(2 \%) \text { of all patients. } \\
\text { - Serum creatinine slightly increased but remained within the normal range. } \\
\text { - Higher doses ( } \geq 30 \mathrm{mg} / \mathrm{kg} / \mathrm{d} \text { ) may be required to achieve iron balance. }\end{array}$ \\
\hline $\begin{array}{l}\text { Cancado } \\
2018 \\
{[37]}\end{array}$ & $\begin{array}{l}\text { Multicenter, } \\
\text { Non- } \\
\text { interventional, } \\
\text { Observational } \\
\text { study }\end{array}$ & $\begin{array}{l}\text { Argentina, } \\
\text { Brazil, } \\
\text { Colombia, } \\
\text { Mexico, } \\
\text { Venezuela }\end{array}$ & $\begin{array}{l}\mathrm{SCD} \\
\mathrm{n}=91\end{array}$ & $\begin{array}{l}\text { - Patients with transfusion-dependent } \\
\text { anemias including SCD (except } \\
\text { thalassemia). } \\
>10 \text { years of age } \\
\cdot \text { ICT in } 55.4 \% \text { of all patients; } \\
\text {-DFX }(n=88 ; 50.3 \%) \\
\text {-DFO }(n=15 ; 8.6 \%) \\
\cdot \text { DFP }(n=7 ; 4 \%)\end{array}$ & $\begin{array}{l}\cdot \geq 1 \text { AE: } 14 \text { patients ( } 8 \%) \text {. } \\
\text { - Grade-3 AEs: } 2 \text { patients (1.1\%). } \\
\text {-AEs requiring concomitant medication: } 3 \text { patients ( } 2.3 \%) \text {. } \\
\text {-AEs related to treatment: } 3 \text { patients (diarrhea, hepatitis, thrombosis, } 0.6 \% \text { each). } \\
\cdot \text { SAE (UTI), prolonged hospitalization without interruption of DFX treatment:1 } \\
\text { patient } \\
\cdot \text { AE (hepatobiliary disorder) resulting in discontinuation of treatment: } 1 \text { patient. } \\
\cdot \text { No deaths during the study period. }\end{array}$ \\
\hline $\begin{array}{l}\text { Mohsin } \\
2018 \\
{[38]}\end{array}$ & $\begin{array}{l}\text { Retrospective, } \\
\text { 3-year }\end{array}$ & $\begin{array}{l}\text { Iraq } \\
\text { (Basra) }\end{array}$ & 102 & $\begin{array}{l}\cdot S C D, \text { sickle/ß thalassemia patients } \\
\cdot \text { DFX } \\
\cdot \text { Ages } \\
<6: n=7 \\
6-10: n=35 \\
10-16: n=43 \\
>16 n=17\end{array}$ & $\begin{array}{l}\text {-AEs: } 38 \text { patients }(37 \%) \\
\text { - The most common; } \\
\text { - abdominal pain }(24.5 \%) \text {, } \\
\text { - diarrhea }(8.0 \%) \\
\text { - nausea }(7.8 \%)\end{array}$ \\
\hline
\end{tabular}




\begin{tabular}{|c|c|c|c|c|c|}
\hline $\begin{array}{l}\text { Calvaruso } \\
2014 \\
{[30]}\end{array}$ & $\begin{array}{l}\text { Multicenter, } \\
\text { Randomized } \\
\text { clinical trial, 5- } \\
\text { year }\end{array}$ & $\begin{array}{l}\text { Italy } \\
\text { (9 centers) }\end{array}$ & 60 & $\begin{array}{l}\cdot \text { SCD patients }>13 \text { years of age } \\
\text { - DFP vs. DFO }(1: 1)\end{array}$ & $\begin{array}{l}\text { - Similar AE incidence between DFP and DFO groups. } \\
\text { - No significant difference in survival }(p=0.38) \text {. } \\
\text { - Causes of death were not related to iron overload or chelation therapy. }\end{array}$ \\
\hline $\begin{array}{l}\text { Vichinsky } \\
2013 \\
{[33]}\end{array}$ & $\begin{array}{l}\text { Prospective, } \\
\text { Randomized, } \\
\text { Phase II study }\end{array}$ & $\begin{array}{l}\text { Canada, USA } \\
\text { (33 centers) }\end{array}$ & 203 & $\begin{array}{l}\cdot S C D \geq 2 \text { years with iron overload, 24- } \\
\text { week randomized comparison: } \\
\text { - DFX }(n=135) \\
\text { - DFO }(n=68) \\
\text { - Then } 2 \text { years of DFX (n=188); } \\
\text { - No HU ( } n=160) \text {, } \\
\text { - With HU }(n=28) \text {. }\end{array}$ & $\begin{array}{l}\text { - Slightly less common AEs in DFX-group }(110 / 135 ; 81.5 \%) \text { as compared to DFO- } \\
\text { group ( } 52 / 56 ; 92.9 \%) \text {. } \\
\text { - During } 2 \text { years of DFX treatment, AEs reported in } 63 / 188(33.5 \%) \text { patients. } \\
\text { - The most common AEs related with DFX were diarrhea }(11.7 \%) \text {, nausea }(6.9 \%) \text {, } \\
\text { and abdominal pain }(5.3 \%) \text {. There was a single case of acute renal failure. } \\
\text { - The most common AE in the DFO group was injection-site pain irritation. }\end{array}$ \\
\hline $\begin{array}{l}\text { Goldberg } \\
2013 \\
{[31]}\end{array}$ & $\begin{array}{l}\text { Multicenter, } \\
\text { Single-arm, } \\
\text { Open-label, } \\
\text { 16-weeks }\end{array}$ & $\begin{array}{l}\text { USA } \\
\text { (20 centers) }\end{array}$ & $\begin{array}{l}\operatorname{SCD} \\
\mathrm{n}=25\end{array}$ & $\begin{array}{l}\text {-SCD, thalassemia major, } \\
\text { myelodysplastic syndrome patients } \\
>2 \text { years of age. } \\
\text { - Run-in phase: 1-month, DFX acc. to } \\
\text { prescribing info), } \\
\text { - Assessment phase: 3-months, with } \\
\text { 5- new modes of DFX oral } \\
\text { administration }\end{array}$ & $\begin{array}{l}\text { - Less patients had GI related AEs with the new DFX administration modes ( } P= \\
0.05) \\
\text { - Possibly positive impact of different administration options on adherence. }\end{array}$ \\
\hline $\begin{array}{l}\text { Alvarez } \\
2013 \\
{[29]}\end{array}$ & $\begin{array}{l}\text { Multicenter, } \\
\text { Randomized, } \\
\text { Phase III }\end{array}$ & $\begin{array}{l}\text { USA } \\
\text { ( } 25 \text { centers) }\end{array}$ & 133 & $\begin{array}{l}\cdot \text { SCA and prior stroke } \\
\cdot \text { Age range } 5-19 \text { years } \\
\text { - Average } 7 \text { years of chronic }\end{array}$ & $\begin{array}{l}\text { - Total AEs in the; } \\
\text { - standard arm: } 64 \text { patients }(97 \%) \\
\text { - alternative arm: } 64 \text { patients }(95.5 \%)(P>0.999)\end{array}$ \\
\hline
\end{tabular}




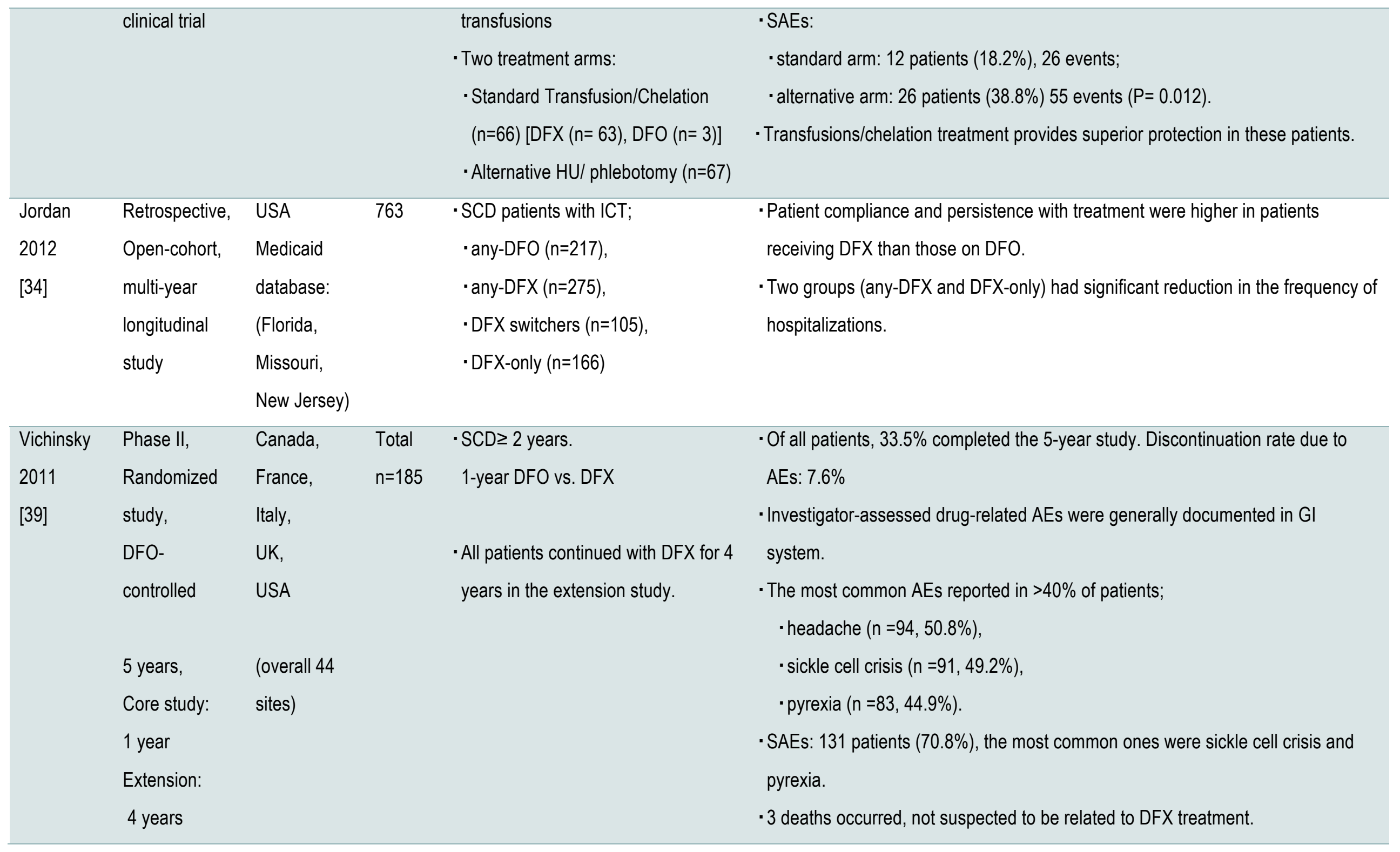




\begin{tabular}{|c|c|c|c|c|c|}
\hline $\begin{array}{l}\text { Kalpatthi } \\
2010 \\
{[40]}\end{array}$ & $\begin{array}{l}\text { Retrospective, } \\
\text { Longitudinal } \\
\text { study } \\
(1993-2004)\end{array}$ & $\begin{array}{l}\text { USA } \\
\text { (single } \\
\text { center) }\end{array}$ & 27 & $\begin{array}{l}\text { Patients received IV DFO } 15 \mathrm{mg} / \mathrm{kg} / \mathrm{hr} \\
\text { for } 48 \mathrm{hr} \text { every... } \\
\cdot 2 \text { weeks }(n=20), \\
\cdot 3 \text { weeks }(n=4), \\
\cdot 4 \text { weeks }(n=3) .\end{array}$ & $\begin{array}{l}\text { - High frequency DFO was well-tolerated (without any major toxicity). } \\
\text { - No ophthalmologic or pulmonary complications. } \\
\text {-A case of mild sensori-neural hearing loss, unrelated with ICT. } \\
\text { - No significant increase in serum creatinine (excluding one patient). }\end{array}$ \\
\hline $\begin{array}{l}\text { Cappelini } \\
2010 \\
{[41]}\end{array}$ & $\begin{array}{l}\text { Prospective, } \\
\text { 1-year, } \\
\text { multicenter, } \\
\text { open-label } \\
\text { phase Illb trial }\end{array}$ & 23 countries & $\begin{array}{l}\text { SCD } \\
(n=80)\end{array}$ & $\begin{array}{l}\text { thalassemia, myelodysplastic } \\
\text { syndromes, aplastic anemia, SCD, } \\
\text { rare/ other transfused anemias. }\end{array}$ & $\begin{array}{l}\cdot \text { Diarrhea }(n=9,11.3 \%) \\
\cdot \text { Skin rash }(n=3,(3.7 \%) \\
\text { - Nausea }(n=5,6.3 \%) \\
\text { - Abdominal pain }(n=1,1.3 \%) \\
\text { - Upper abdominal pain }(n=5,6.3 \%) \\
\text { - Vomiting }(n=3,3.7 \%)\end{array}$ \\
\hline
\end{tabular}

AE, adverse event; DFO, deferoxamine; DFP, deferiprone; DFX, deferasirox; HU, hydroxyurea; ICT, iron chelation therapy; SC, subcutaneous; SCA, sickle cell anemia; SCD, sickle cell disease; SAE, serious adverse event; TDT, transfusion-dependent thalassemia; UTI, urinary tract infection. 
In the case of adverse reactions (adverse events: $A E s$, serious adverse events: SAEs) related to the use of chelating agents, it has been clearly shown that these agents reveal high tolerability. Moreover, the number of SAEs that were considered to be related to iron chelation treatment in SCD patients has been rarely observed. In the 11 trials evaluated in this review, the most commonly reported $A E s$ associated with iron chelation therapy appears as gastrointestinal disorders. However, drug related $\mathrm{AEs}$ and toxicity that have been observed are mostly tolerable. It has been shown that gastrointestinal adverse reactions associated with DFX use can be reduced using new oral administration recommendations. Goldberg et al. have compared the prescription administration recommendation of DFX, to be taken 30 minutes before of 2 hours after meals on an empty stomach, with the new oral administration modes of DFX; to be taken either at breakfast or at dinner with soft food or beverage of choice, or with no meal with a beverage of choice, in terms of gastrointestinal adverse reactions [31]. Interestingly, the most recent trial that was conducted in Turkey revealed that $32.4 \%$ of patients had at least one $A E$, while $12.9 \%$ had SAE [32]. Moreover, $1.3 \%$ of the participants had to discontinue therapy, whereas $1.8 \%$ had $A E s$ requiring drug dose adjustment or interruption esp. hepatic enzyme elevation. The authors stated that only $2 \%$ of patients had AEs suspected to be related to DFX, with the most common being hepatic enzyme increase, followed by very rare renal tubular disorder (one serious case), increased blood creatinine, abdominal pain, and proteinuria.

In terms of comparison of three iron chelators, no significant difference was reported for the adverse reactions and survival rates [30, 33]. However, considering patient compliance and persistence, these studies underline the higher advantage of DFX over DFO. This might be mainly due to the once a day oral administration of DFX [34].

\section{CONCLUSION}

SCD remains one of the most common serious inherited hemoglobinopathies; however, in the last decades the survival- and health-related quality of life have improved considerably, with more effective use of newborn screening, penicillin prophylaxis, vaccinations, therapeutic agents and education [35]. In addition, blood or RBC transfusion in SCD can effectively reduce some of the most serious complications of SCD, including stroke and acute chest syndrome [25]. In this context, iron chelation therapy has become a critical component of the transfusion program to prevent complications of iron accumulation in patients receiving multiple transfusions [17].

Results of the studies conducted in the last 10 years evaluating the safety of chelators used for transfusion-induced iron overload in SCD has no significant differences in terms of adverse reactions and survival, among the three iron chelators (DFO, DFP and DFX). However, when patient compliance and persistence are considered, DFX was found to have advantage over DFO, which might arise from ease of administration of DFX (once a day, oral). Moreover, the most common adverse reactions with DFX appear to be associated with the gastrointestinal system and these noxious actions may be reduced via new oral administration modes [31]. On the other hand, DFP treatment-related studies assessing both the safety and effectiveness are relatively limited. This could be explained by the fact that DFP is a chelator that is seldom used without an evidence of cardiac iron overload [36].

Overall, current evidence shows that when the risks of iron overload and the complications of untreated SCD are considered, iron chelation therapy is a relatively safe and generally a requisite in transfused patients. Besides these findings, because of the rarity of studies evaluating iron chelation treatment for special groups, such as patients with pregnancy or comorbidity, and limitations of the conducted studies, new studies are warranted to develop detailed treatment guidelines and medical care for these groups.

\section{CONFUCT Of INTEREST STATEMENT}

The authors have no conflict of interest. 
[1] Williams TN, Weatherall DJ. World distribution, population genetics, and health burden of the hemoglobinopathies. Cold Spring Harb Perspect Med 2012; 2(9): a011692.

[2] Piel FB, Tatem AJ, Huang Z, et al. Global migration and the changing distribution of sickle haemoglobin: a quantitative study of temporal trends between 1960 and 2000. Lancet Glob Heal 2014; 2(2): e80-9.

[3] Piel FB, Hay SI, Gupta S, et al. Global burden of sickle cell anaemia in children under five, 2010-2050: Modelling based on demographics, excess mortality, and interventions. PLoS Med 2013; 10(7): e1001484.

[4] Ashley-Koch A, Yang Q, Olney RS. Sickle hemoglobin (HbS) allele and sickle cell disease: a HuGE review. Am J Epidemiol 2000; 151(9): 839-45.

[5] Kato GJ, Piel FB, Reid CD, et al. Sickle cell disease. Nat Rev Dis Prim 2018; 4: 18010.

[6] Redding-Lallinger R, Knoll C. Sickle cell disease--pathophysiology and treatment. Curr Probl Pediatr Adolesc Health Care.2006; 36(10): 346-76.

[7] Chirico EN, Pialoux V. Role of oxidative stress in the pathogenesis of sickle cell disease. IUBMB Life 2012; 64(1): 72-80.

[8] Aslan M, Ryan TM, Adler B, et al. Oxygen radical inhibition of nitric oxide-dependent vascular function in sickle cell disease. Proc Natl Acad Sci 2001; 98(26): 15215-20.

[9] Voskou S, Aslan M, Fanis P, et al. Oxidative stress in $\beta$-thalassaemia and sickle cell disease. Redox Biol 2015; 6: 226-39.

[10] Oztas Y, Durukan I, Unal S, et al. Plasma protein oxidation is correlated positively with plasma iron levels and negatively with hemolysate zinc levels in sickle-cell anemia patients. Int J Lab Hematol 2012; 34(2): 129-35.

[11] Lobitz S, Telfer P, Cela E, et al. Newborn screening for sickle cell disease in Europe: recommendations from a Pan-European Consensus Conference. Br J Haematol 2018;183(4) : 648-60.

[12] Kapoor S, Little JA, Pecker LH. Advances in the Treatment of Sickle Cell Disease. Mayo Clin Proc 2018; 93(12): 1810-24.

[13] Gluckman E. Allogeneic transplantation strategies including haploidentical transplantation in sickle cell disease. Hematology Am Soc Hematol Educ Program 2013; 2013: 370-6.

[14] Mulaku M, Opiyo N, Karumbi J, et al. Evidence review of hydroxyurea for the prevention of sickle cell complications in low-income countries. Arch Dis Child 2013; 98(11): 908-14.

[15] Niihara Y, Miller ST, Kanter J, et al. A phase 3 trial of L-glutamine in sickle cell disease. N Engl J Med 2018; 379(3): 226-35.

[16] Niihara Y, Zerez CR, Akiyama DS, et al. Oral L-glutamine therapy for sickle cell anemia: I. subjective clinical improvement and favorable change in red cell NAD redox potential. Am J Hematol 1998; 58(2): 117-21.

[17] Porter J, Garbowski M. Consequences and management of iron overload in sickle cell disease. Hematology Am Soc Hematol Educ Program 2013; 2013: 447-56.

[18] DeBaun MR, Vichinsky EP (Section Eds: Schrier SL, Mahoney DH, Jr; Deputy Eds: Tirnauer JS, Vichinsky EP, Schrier SL). Red blood cell transfusion in sickle cell disease. https://www.uptodate.com/contents/red-blood-cell-transfusion-in-sickle-celldisease (accessed May 2019).

[19] Thein SL, Howard J. How I treat the older adult with sickle cell disease. Blood 2018; 132(17): 1750-60.

[20] Wood JC, Cohen AR, Pressel SL, et al. Organ iron accumulation in chronically transfused children with sickle cell anaemia: baseline results from the TWiTCH trial. Br J Haematol 2016; 172(1): 122-30.

[21] Tavares AHJ, Benites BD, Fertrin KY. Myocardial iron overload in sickle cell disease: A rare but potentially fatal complication of transfusion. Transfus Med Rev 2019; 33(3):170-175.

[22] Estcourt LJ, Fortin PM, Hopewell S, et al. Red blood cell transfusion to treat or prevent complications in sickle cell disease: an overview of Cochrane reviews. Cochrane Database Syst Rev 2016; 2016(2). pii: CD012082.

[23] Schrier SL, Bacon BR (Section Ed: Mentzer WC; Deputy Ed: Tirnauer JS). Iron chelators: Choice of agent, dosing, and adverse effects. https://www.uptodate.com/contents/ironchelators-choice-of-agent-dosing-and-adverse -effects?search $=$ Iron $\% 20$ chelators $\% 20$ Choice $\% 20$ of\%20agent, $\% 20$ dosing, \%20and \%20adverse\%20effects\&source=search_result \&selectedTitle=1 150\&usage_type=default\&display_ rank=1 (accessed May 2019).

[24] De Montalembert M, Ribeil JA, Brousse V, et al. Cardiac iron overload in chronically transfused patients with thalassemia, sickle cell anemia, or myelodysplastic syndrome. PLoS One 2017; 12(3): e0172147.

[25] Chou ST. Transfusion therapy for sickle cell disease: a balancing act. Hematology Am Soc Hematol Educ Program 2013; 2013: 439-46.

[26] Coates TD, Wood JC. How we manage iron overload in sickle cell patients. Br J Haematol 2017; 177(5): 703-16.

[27] Botzenhardt S, Li N, Chan EW, et al. Safety profiles of iron chelators in young patients with haemoglobinopathies. Eur J Haematol 2017; 98(3): 198-217.

[28] Moher D, Shamseer L, Clarke M, et al. Preferred reporting items for systematic review and meta-analysis protocols (PRISMA-P) 2015 statement. Syst Rev 2015; 4:1.

[29] Alvarez O, Yovetich NA, Scott JP, et al. Pain and other non-neurological adverse events in children with sickle cell 
anemia and previous stroke who received hydroxyurea and phlebotomy or chronic transfusions and chelation: results from the SWiTCH clinical trial. Am J Hematol 2013; 88(11): 932-8.

[30] Calvaruso G, Vitrano A, Di Maggio R, et al. Deferiprone versus deferoxamine in sickle cell disease: results from a 5 -year long-term Italian multi-center randomized clinical trial. Blood Cells Mol Dis 2014; 53(4): 265-71.

[31] Goldberg SL, Giardina PJ, Chirnomas D, et al. The palatability and tolerability of deferasirox taken with different beverages or foods. Pediatr Blood Cancer 2013; 60(9):1507-12.

[32] Antmen B, Karakaş Z, Yeşilipek MA, et al. Deferasirox in children with transfusion-dependent thalassemia or sickle cell anemia: A large cohort real-life experience from Turkey (REACHTHEM). Eur J Haematol. 2019; 102(2): 123-30.

[33] Vichinsky E, Torres M, Minniti CP, et al. Efficacy and safety of deferasirox compared with deferoxamine in sickle cell disease: Two-year results including pharmacokinetics and concomitant hydroxyurea. Am J Hematol 2013; 88(12): 1068-73.

[34] Jordan LB, Vekeman F, Sengupta A, et al. Persistence and compliance of deferoxamine versus deferasirox in Medicaid patients with sickle-cell disease. J Clin Pharm Ther 2012; 37(2): 173-81.

[35] Ware RE, de Montalembert M, Tshilolo L, Abboud MR.
Sickle cell disease. Lancet 2017; 390: 311-23.

[36] Raghupathy R, Manwani D, Little JA. Iron overload in sickle cell disease. Adv Hematol. 2010; 2010: 272940.

[37] Cancado R, Watman NP, Lobo C, et al. Assessment of liver and cardiac iron overload using MRI in patients with chronic anemias in Latin American countries: results from ASIMILA study. Hematology 2018; 23(9): 676-82.

[38] Mohsin A, Hassan M. A 3-year study of deferasirox therapyn sickle cell disease patients in Basra, Southern Iraq. Niger J Clin Pract. 2018; 21(6): 735-42.

[39] Vichinsky E, Bernaudin F, Forni GL, et al. Long-term safety and efficacy of deferasirox (Exjade ${ }^{\oplus}$ ) for up to 5 years in transfusional iron-overloaded patients with sickle cell disease. $\mathrm{Br} \mathrm{J}$ Haematol 2011; 154(3): 387-97.

[40] Kalpatthi R, Peters B, Kane I, et al. Safety and efficacy of high dose intravenous desferrioxamine for reduction of iron overload in sickle cell disease. Pediatr Blood Cancer 2010; 55(7): 1338-42.

[41] Cappellini MD, Porter J, El-Beshlawy A, et al. Tailoring iron chelation by iron intake and serum ferritin: The prospective EPIC study of deferasirox in 1744 patients with transfusion-dependent anemias. Haematologica 2010; 95(4): 557-66. 